\title{
A missense mutation in Fgfrl causes ear and skull defects in hush puppy mice
}

\author{
Jennifer A. Calvert $\cdot$ Skarlatos G. Dedos • \\ Kelvin Hawker • Michelle Fleming • \\ Morag A. Lewis · Karen P. Steel
}

Received: 7 January 2011/Accepted: 9 March 2011/Published online: 10 April 2011

(C) The Author(s) 2011. This article is published with open access at Springerlink.com

\begin{abstract}
The hush puppy mouse mutant has been shown previously to have skull and outer, middle, and inner ear defects, and an increase in hearing threshold. The fibroblast growth factor receptor $1(F g f r l)$ gene is located in the region of chromosome 8 containing the mutation. Sequencing of the gene in hush puppy heterozygotes revealed a missense mutation in the kinase domain of the protein (W691R). Homozygotes were found to die during development, at approximately embryonic day 8.5, and displayed a phenotype similar to null mutants. Reverse transcription PCR indicated a decrease in Fgfrl transcript in heterozygotes and homozygotes. Generation of a construct containing the mutation allowed the function of the mutated receptor to be studied. Immunocytochemistry showed that the mutant receptor protein was present at the cell membrane, suggesting normal expression and trafficking. Measurements of changes in intracellular calcium
\end{abstract}

Electronic supplementary material The online version of this article (doi:10.1007/s00335-011-9324-8) contains supplementary material, which is available to authorized users.

J. A. Calvert · M. Fleming · M. A. Lewis · K. P. Steel ( $\square)$

Wellcome Trust Sanger Institute, Wellcome Trust Genome

Campus, Hinxton, Cambridge CB10 1SA, UK

e-mail: kps@sanger.ac.uk

S. G. Dedos

Department of Pharmacology, University of Cambridge,

Cambridge, UK

K. Hawker

MRC Institute of Hearing Research, Nottingham, UK

Present Address:

S. G. Dedos

Department of Zoology and Marine Biology, Faculty of Biology,

National and Kapodistrian University of Athens, Athens, Greece concentration showed that the mutated receptor could not activate the $\mathrm{IP}_{3}$ pathway, in contrast to the wild-type receptor, nor could it initiate activation of the Ras/MAP kinase pathway. Thus, the hush puppy mutation in fibroblast growth factor receptor 1 appears to cause a loss of receptor function. The mutant protein appears to have a dominant negative effect, which could be due to it dimerising with the wild-type protein and inhibiting its activity, thus further reducing the levels of functional protein. A dominant modifier, Mhspy, which reduces the effect of the hush puppy mutation on pinna and stapes development, has been mapped to the distal end of chromosome 7 and may show imprinting.

\section{Introduction}

Genetic defects play a major role in the causation of hearing impairment in the human population and many different genes can be involved. More than 130 loci have been identified for nonsyndromic deafness alone, with additional loci involved in syndromic deafness (for review see Nance 2003; Van Camp and Smith (2011). Although it is expected that many more novel genes are yet to be identified, in many cases the role of those genes already known to be associated with deafness are not fully understood. Mouse models of deafness can be used to study the effects of mutated genes, with the aim of correlating the phenotypic consequences of the mouse mutations to human conditions.

The hush puppy mutant (gene symbol Hspy) was identified in an $N$-ethyl- $N$-nitrosourea (ENU) screening programme (Hrabé de Angelis et al. 2000). The phenotype of heterozygous mutant mice was described previously (Pau et al. 2005). Hush puppy heterozygotes were found to have 
defects in all regions of the ear. In the outer ear the pinna was small, misshapen, and low-set on one or both sides. In the middle ear the stapes were malformed in both ears and incus abnormalities were also found in some cases. Preliminary scanning electron microscopy studies of the inner ear indicated that small regions of the organ of Corti had two rows of outer hair cells instead of the usual three rows. Hearing impairment varied between individual animals, but compound action potential thresholds revealed that all heterozygotes had some increase in thresholds compared to littermate controls. In addition to the ear phenotype, the skull and mandible were shorter in the anteroposterior axis. There was a large amount of variation in the phenotype between individual animals, indicating that there was not full penetrance of the phenotype. For example, penetrance for the pinna defect was estimated at $71 \%$. Genetic mapping of the mutation isolated it to chromosome 8 between markers D8Mit58 and D8Mit289.

The tyrosine kinase receptor fibroblast growth factor receptor $1(F g f r l)$ was a very good candidate gene within the identified region because it is known to be expressed in the inner ear, where it is required for development of the auditory sensory epithelium (Pirvola et al. 2002). Stimulation of Fgfr1 by fibroblast growth factors (FGFs) leads to dimerisation and autophosphorylation of the receptor into its active form. The activated receptor interacts with several pathways, including the Ras/MAP kinase pathway and the PLC $\gamma / \mathrm{IP}_{3}$ pathway (for review see Eswarakumar et al. 2005). Previous studies have shown that Fgfr1 is involved in a wide variety of processes, including cell migration during gastrulation (Deng et al. 1994; Yamaguchi et al. 1994), patterning of the anteroposterior axis (Hajihosseini et al. 2004; Partanen et al. 1998), craniofacial morphogenesis (Lee et al. 2008; Riley et al. 2007; Rizzoti and Lovell-Badge 2007), segmentation of the presomitic mesoderm (Wahl et al. 2007), and development of sensory organs (Hebert et al. 2003; Pirvola et al. 2002).

The current study has identified a single-point mutation in the Fgfrl gene in the hush puppy mutant. This mutation leads to an amino acid substitution in the kinase domain of the receptor. Study of the homozygote phenotype revealed that the mutation is lethal at approximately embryonic day (E) 8.5, confirming the role of Fgfr1 in early development (Hoch and Soriano 2006). Mutant protein is detected at the cell membrane as normal, but functional studies showed that the mutation causes loss of activation of the Ras/MAP kinase and PLC $\gamma / \mathrm{IP}_{3}$ pathways. The severity of the heterozygote phenotype implies that the mutant protein may be exerting a dominant negative effect, possibly by dimerising with and inhibiting the activity of wild-type protein. In addition, we found evidence of modifiers in the C57BL/6J genome that ameliorate the effect of the Hspy mutation. The effects have been analysed using a backcross panel, and a dominant modifier, Mhspy, has been localised to the distal end of chromosome 7. Mhspy shows different effects depending on whether it is inherited from the mother or the father, consistent with imprinting.

\section{Methods}

\section{Mutant mice}

The founder mouse (carrying the hush puppy mutation; DEA9) was generated in a large-scale $N$-ethyl- $N$-nitrosourea (ENU) mutagenesis programme (Hrabé de Angelis et al. 2000; Pau et al. 2005). The colony was maintained by heterozygote $x$ wild-type matings on a $\mathrm{C} 3 \mathrm{HeB} / \mathrm{FeJ}$ background, and heterozygote $\times$ heterozygote matings were used to produce the homozygotes for analysis. Age-matched wild-type littermates were used as controls. Once the gene was identified, DNA was extracted from each animal and genotyped using PCR primers 1 and 2 (Table 1), which introduced a $D d e$ I restriction site into DNA that contained the mutation. The PCR product was then digested with DdeI $(100 \mathrm{U} / \mathrm{ml})$ overnight at $37^{\circ} \mathrm{C}$, and the resulting fragments were viewed using ethidium bromide agarose gel electrophoresis. Wild-type DNA gave a single band of $208 \mathrm{bp}$, heterozygote DNA showed as two bands at 184 and $208 \mathrm{bp}$, and homozygote mutant DNA gave one band at $184 \mathrm{bp}$.

\section{Sequencing}

DNA was extracted from wild-type and heterozygous animals. Primers were designed with the aid of Primer3 (Rozen and Skaletsky 2000) to amplify each exon of Fgfrl. PCR conditions were as follows: denaturation at $94^{\circ} \mathrm{C}$ for $5 \mathrm{~min}$; 35 cycles of denaturation at $94^{\circ} \mathrm{C}$, followed by annealing at $58^{\circ} \mathrm{C}$ and extension at $72^{\circ} \mathrm{C}$ for $30 \mathrm{~s}$ each; final extension at $72^{\circ} \mathrm{C}$ for $5 \mathrm{~min}$. PCR products were then sequenced and the resulting sequences were examined using GAP4 software (Bonfield et al. 1995).

\section{RT-PCR}

Whole embryos, including the yolk sac, were dissected at E8.5 and snap-frozen in liquid nitrogen. Total RNA was isolated using the RNeasy Mini Kit (Qiagen, Valencia, CA, USA). The RNA was treated with DNase I (Sigma, UK) to remove any DNA contamination. Half of the purified RNA was reverse-transcribed to cDNA using SuperScript II-reverse transcriptase (Invitrogen, Carlsbad, CA, USA), and the remainder of the RNA was used as a negative control. PCR reactions were carried out with $0.5 \mu \mathrm{l}$ of cDNA and a final concentration of $500 \mathrm{nM}$ of each primer. 
Table 1 Primer sequences for genotyping (1 and 2), RT-PCR (3-6), and clone mutagenesis (7-15)

\begin{tabular}{llll}
\hline Primer & Function & Direction & Sequence $\left(5^{\prime}-3^{\prime}\right)$ \\
\hline 1 & Genotyping & Forward & GTGGTCTTTTGGAGTGCTCCTG \\
2 & Genotyping & Reverse & GCTTGCCAGTGGTGGATCCAA \\
3 & Fgfr1 & Forward & CCGGATCTACACACACCAGA \\
4 & Fgfr1 & Reverse & CCACCAACTGCTTGAACGTA \\
5 & $\beta$-actin & Forward & ATCCATGAAACTACATTCAATTCCAT \\
6 & $\beta$-actin & Reverse & ACCGATCCACACAGAGTACTTGCGC \\
7 & ORF & Forward & GATCAGTCGACGCCACCATGTGGGGCTGGAAGTGCCTCCTC \\
8 & ORF & Reverse & GATCAGAATTCTCAGCGCCGTTTGAGTCCACTGTTGGCAAGCTGGGT \\
9 & E265 K & Forward & CAGGGCTGCCTGCCAACAAGACAGTGGCCCTGGGC \\
10 & P457L & Forward & CAGCGGGACCCCCATGCTGGCTGGAGTCTCCGAATATG \\
11 & S763 N & Forward & CATTGTGGCCTTGACCTCCAACCAGGAGTATCTGGACCTG \\
12 & Flag tag & Forward & AGGTTGGGGCTGGCCTGGCCTTATCGTCATCGTCTTTGTAGTCAGTGCAGAGAGTGGCTGTG \\
13 & Flag tag & Reverse & CACAGCCACTCTCTGCACTGACTACAAAGACGATGACGATAAGGCCAGGCCAGCCCCAACCT \\
14 & Hspy & Forward & GGTCTTTTGGAGTGCTCTTGAGGGAGATCTTCACTCTGGG \\
15 & Hspy & Reverse & CCCAGAGTGAAGATCTCCCTCAAGAGCACTCCAAAAGACC \\
\hline
\end{tabular}

$O R F$ open reading frame

PCR and electrophoresis were performed as described above, with the exceptions that the annealing temperature was $57^{\circ} \mathrm{C}$ and only 30 cycles were used. The primers for Fgfrl (Table 1, primers 3 and 4) were designed to encompass the mutation in order to genotype embryos by sequencing the amplified products (as described above). Primers for $\beta$-actin (Table 1, primers 5 and 6) were used as an internal control. To quantify the relative change in transcript level between genotypes, band intensities were measured using ImageJ (http://rsb.info.nih.gov/ij/index. html). Background levels of luminescence were subtracted from mean band intensities, and Fgfrl transcript level was normalised to $\beta$-actin transcript.

\section{Clone mutagenesis}

The full-length cDNA of murine Fgfrl in pBlueScript was obtained from ATCC [Manassas, VA, USA; pBSmFGFR(L), clone number 63344 (Jin et al. 1994)]. The open reading frame of $m F g f r l$ was amplified by PCR from the full-length cDNA using Pfx DNA polymerase (Invitrogen) and primers 7 and 8 (Table 1). After digestion with SalI-EcoRI, the PCR product was ligated into pENTR1a (Invitrogen) to generate vector pENTR1a-mFgfrl. Comparison of the predicted amino acid sequence to that of $F g f r l$ from wild-type mice with the same genetic background as hush puppy $(\mathrm{C} 3 \mathrm{HeB} /$ FeJ) revealed three amino acid differences caused by single nucleotide changes: E265 $\rightarrow \mathrm{K}, \mathrm{P} 457 \rightarrow \mathrm{L}, \mathrm{S} 763 \rightarrow \mathrm{N}$. These differences were corrected in vector pENTR1a$m F g f r l$ using a QuikChange ${ }^{\circledR}$ multisite-directed mutagenesis kit (Stratagene, Agilent Technologies, Santa Clara, CA, USA) and primers 9,10 , and 11 , to create vector $F g f r l^{W T}$. In this vector, a flag-tag epitope (DYKDDDDK) was inserted after the signal peptide of $m F g f r l$ (between amino acids T20 and A21) by site-directed mutagenesis using a QuikChange ${ }^{\circledR}$ II XL site-directed mutagenesis kit (Stratagene) and primers 12 and 13 to generate vector Fgfrl ${ }^{\text {WT-flag }}$. The hush puppy mutation W691 $\rightarrow$ R was added to Fgfrl ${ }^{\text {WT-flag }}$ with the QuikChange II XL site-directed mutagenesis kit and primers 14 and 15 to generate vector $F g f r l^{\text {Hspy-flag }}$. Vectors $F g f r l^{W T}, F g f r l^{W T-f l a g}$, and $F g f r 1^{\text {Hspy-flag }}$ were recombined into the expression vector pcDNA3.2 using Gateway® LR Clonase Enzyme Mix (Invitrogen).

\section{Cell culture and transfection}

HEK293 cells were chosen for transient expression studies due to their lack of endogenous Fgfr expression but intact MAP kinase pathway (Li et al. 2004). Cells were maintained in culture with D-MEM:F-12 media supplemented with foetal bovine serum $(10 \%)$, glutamine $(292 \mu \mathrm{g} / \mathrm{ml})$, penicillin $(100 \mathrm{U} / \mathrm{ml})$, and streptomycin $(100 \mu \mathrm{g} / \mathrm{ml})$. Cells were plated into 6- or 24-well plates as required and allowed to adhere for at least $24 \mathrm{~h}$. Transient transfections were performed using Lipofectamine 2000 (Invitrogen).

Immunocytochemistry

HEK293 cells were plated onto 13-mm coverslips coated with poly-L-lysine $(0.01 \%)$ and were transfected with $0.5 \mu \mathrm{g}$ of vector DNA per coverslip as described above. Approximately $24 \mathrm{~h}$ after transfection, cells were washed twice with Tris-buffered saline (TBS: $10 \mathrm{mM}$ Trizma base, 
$150 \mathrm{mM} \mathrm{NaCl}, \mathrm{pH}$ 7.4) and fixed in methanol and acetone (1:1) for $1 \mathrm{~min}$. Coverslips were washed three times with TBS. Anti-flag antibody conjugated to FITC $(10 \mu \mathrm{g} / \mathrm{ml}$; Sigma) was applied to each coverslip for $1 \mathrm{~h}$ at room temperature. Coverslips were washed three times with TBS before being mounted onto glass slides. Cells were then examined under a fluorescence microscope at $488 \mathrm{~nm}$ and pictures were taken using AxioVision (release 4.3) software.

\section{Single-cell calcium imaging}

Single-cell calcium imaging (Tovey et al. 2003) was performed on transiently transfected cells to determine if the mutated Fgfr1 receptor could activate the $\mathrm{IP}_{3}$ signalling pathway. HEK293 cells were plated onto 22-mm coverslips and transfected with the appropriate vector DNA. Twentyfour hours post transfection, cells were loaded with $2 \mu \mathrm{M}$ fura-2/AM for $1 \mathrm{~h}$ at room temperature. Coverslips were washed in $\mathrm{HBS}(135 \mathrm{mM} \mathrm{NaCl}, 5.9 \mathrm{mM} \mathrm{KCl}, 1.2 \mathrm{mM}$ $\mathrm{MgCl}_{2}, 1.5 \mathrm{mM} \mathrm{CaCl} 2,11.6 \mathrm{mM}$ HEPES, $11.5 \mathrm{mM}$ glucose, $\mathrm{pH} \mathrm{7.2)} \mathrm{for} 30 \mathrm{~min}$ at room temperature and were then imaged. Cells were excited alternately at 340 and $380 \mathrm{~nm}$ for $500 \mathrm{~ms}$ each using a monochromator (Cairn, UK). Emitted fluorescence was collected at $510 \mathrm{~nm}$, and images were recorded using a MicroMax 1300Y/HS CCD camera (Princeton Instruments UK, Buckinghamshire, UK). Data was collected and analysed using Metafluor software (Molecular Devices, Sunnyvale, CA, USA). Cells were stimulated with $100 \mathrm{ng} / \mathrm{ml} \mathrm{FGF1}$ with $5 \mu \mathrm{g} / \mathrm{ml}$ heparin for $5 \mathrm{~min}$, with data sampled every $5 \mathrm{~s}$. To ensure that cells selected were capable of responding, they were then exposed to $1 \mathrm{mM}$ carbachol (CCh) for $2 \mathrm{~min}$. Fifty cells were selected from each experiment for analysis, and any that failed to respond to $\mathrm{CCh}$ were discarded. Each experiment was performed on two independent transfections. Traces were corrected for baseline $\left[\mathrm{Ca}^{2+}\right]_{i}$, and the fluorescence ratios $\left(\mathrm{F}_{340} / \mathrm{F}_{380}\right)$ for individual cells were calculated. These ratios were then calibrated to $\left[\mathrm{Ca}^{2+}\right]_{i}$ by referencing a lookup table created using standard $\mathrm{Ca}^{2+}$ solutions (Molecular Probes Calcium Calibration Kit with $1 \mathrm{mM} \mathrm{MgCl}$ ), using the following equation (Grynkiewicz et al. 1985):

$\left[\mathrm{Ca}^{2+}\right]_{\mathrm{i}}=K_{\mathrm{d}} \cdot Q\left[\left(R-R_{\min }\right) /\left(R_{\max }-R\right)\right]$

where $K_{\mathrm{d}}$ is the dissociation constant for fura-2 binding to $\mathrm{Ca}^{2+}(140 \mathrm{nM}) ; R$ is the fluorescence ratio $\left(\mathrm{F}_{340} / \mathrm{F}_{380}\right)$ at any given experimental time point; $R_{\min }$ is the minimum fluorescence ratio determined in $\mathrm{Ca}^{2+}$-free media $(10 \mathrm{mM}$ EGTA); $R_{\max }$ is the maximum fluorescence ratio determined in the presence of saturating $\left[\mathrm{Ca}^{2+}\right](\sim 37 \mu \mathrm{M}$ free $\mathrm{Ca}^{2+}$ ); and $Q$ is $\mathrm{F}_{\max } / \mathrm{F}_{\min }$ at $380 \mathrm{~nm}$.
Cell stimulation and Western blotting

To determine whether the mutant receptor could activate the Ras/MAP kinase pathway, cells were stimulated with agonist and then lysed. Western blotting was then performed on cell lysates to look for phosphorylation of MAP kinase (MAPK) as an indication of activation of the pathway. HEK293 cells were plated onto 6-well plates and transfected with $1 \mu \mathrm{g}$ of the required vector DNA per well. Twenty-four hours after transfection, the medium was removed and cells were placed in serum-free medium for $4 \mathrm{~h}$. Cells were washed with HBS before stimulation. Stimulated cells were exposed to $100 \mathrm{ng} / \mathrm{ml} \mathrm{FGF1}$ and $5 \mu \mathrm{g} / \mathrm{ml}$ heparin in $\mathrm{HBS}$ for $10 \mathrm{~min}$ at $37^{\circ} \mathrm{C}$. Unstimulated cells had HBS applied during this time. Cells were washed with cold HBS and lysed in $1 \mathrm{ml}$ of $1 \times$ IP buffer (from a protein $\mathrm{G}$ immunoprecipitation kit, Sigma). Lysates were incubated on ice for 15-20 min before being centrifuged. The supernatant was removed and stored at $-80^{\circ} \mathrm{C}$ with $10 \%$ glycerol until required.

SDS-PAGE was performed using 7.5\% acrylamide gels. Proteins were transferred onto nitrocellulose membranes using a mini trans-blotter (Bio-Rad Laboratories, Hercules, CA, USA). Membranes were incubated in blocking solution (10\% skimmed milk in TTBS: $50 \mathrm{mM}$ Trizma base, $150 \mathrm{mM} \mathrm{NaCl}, 0.1 \%$ Tween 20, $\mathrm{pH}$ 8) for $1-2 \mathrm{~h}$ before overnight incubation with the primary antibody at $4{ }^{\circ} \mathrm{C}$. Membranes were washed in TTBS before application of secondary antibody (anti-rabbit IgG HRP conjugate, $0.1 \mu \mathrm{g} / \mathrm{ml}$ ). After washing with TTBS, membranes were developed using ECL plus Western blotting detection reagent (Amersham, UK) for $5 \mathrm{~min}$. ECL hyperfilm (Amersham) was used to visualise the bands.

In some cases there were low levels of background phosphorylation of MAPK. To compensate for this, levels of phosphorylated MAPK were expressed as a ratio against total MAPK in each lysate, using ImageJ to measure band intensity, as described above.

\section{Antibodies}

For immunocytochemistry, anti-flag M2 monoclonal FITCconjugated antibodies were obtained from Sigma. Anti-p44/ 42 MAP kinase and anti-phospho-p44/42 MAP kinase antibodies for Western blotting were acquired from Cell Signaling Technology (Danvers, MA, USA). The anti-rabbit IgG HRP secondary antibodies for Western blotting were from Upstate Biotechnologies (Lake Placid, NY, USA).

\section{Mapping the modifiers}

Mice heterozygous for the hush puppy mutation were outcrossed to $\mathrm{C} 57 \mathrm{BL} / 6 \mathrm{~J}$. The resulting F1 offspring were 
genotyped, and then mice carrying the hush puppy mutation were crossed to $\mathrm{C} 3 \mathrm{HeB} / \mathrm{FeJ}$ to produce the backcross mice used for mapping ( $n=379$ backcross mice). Hush puppy heterozygotes from the backcross generation $(n=172)$ were collected between 5 and 8 weeks of age and used for analysis of the stapes phenotype, skull length, and pinna size except the ones excluded as listed below. An additional 26 heterozygous backcross animals were collected between 7.5 and 8 months of age. These animals were not used in the linkage analysis for the pinna and skull because these tissues continue to grow beyond 8 weeks of age. DNA was prepared from all backcross mice and used for a genome scan using a panel of polymorphic dinucleotide repeat markers covering all 19 autosomes (Table 2). There was no evidence from the distribution of phenotypes for any X-linked modifier.

Pinnae were removed from each mouse $(n=172)$ shortly after the mouse was culled. Five mice were not included because of pinna damage. Pinnae were flattened under a microscope slide and photographed at a constant magnification. Each pinna was outlined by hand in Adobe
Photoshop and the surface area was measured using ImageJ.

After removal of the pinnae, heads were skinned and then placed in $10 \%$ neutral buffered formalin for storage prior to dissection of the ossicles. Twenty-seven of the 172 backcross mice had one or both stapes either lost or broken during dissection and could not be used for analysis. An additional 26 backcross mice were collected at 7.5-8 months and processed in the same manner. Stapes were given a score according to how badly affected they were.

Following dissection of the ossicles, the skulls were fixed in ethanol, macerated with potassium hydroxide, stained with Alcian Blue and Alizarin Red, and cleared in glycerol using a standard protocol (Inouye 1976; McLeod 1980).Each skull $(n=172)$ was photographed with a scale. ImageJ was used to measure the length of the skull between the end of the nasal bone and the caudal edge of the interparietal bone. The width of the skull was also measured along the suture at the back of the parietal bone. Nose angle was measured by deviation from the midline of the skull, starting at the base of the nasal bone.

Table 2 Markers used for the genome scan

\begin{tabular}{|c|c|c|c|c|c|}
\hline Marker & Position (cM) & Marker & Position (cM) & Marker & Position (cM) \\
\hline D1Mit429 & 8.4 & D6Mit254 & 60.55 & D13Mit3 & 8.96 \\
\hline D1Mit415 & 53.06 & D7Mit178 & 0.5 & D13Mit88 & 21 \\
\hline D1Mit353 & 90.34 & D7Mit230 & 22.45 & D13Mit9 & 32.44 \\
\hline D2Mit369 & 27.3 & D7Mit66 & 57.5 & D14Mit99 & 1.51 \\
\hline D2Mit 237 & 28 & D7Mit105 & 63.5 & D14Mit260 & 21.21 \\
\hline D2Mit107 & 75.6 & D7Mit259 & 72 & D14Mit 225 & 44.1 \\
\hline D2Mit200 & 98.36 & D8Mit339 & 23 & D14Mit266 & 60 \\
\hline D3Mit117 & 2.35 & D8Mit113 & 52 & D15Mit175 & 5.72 \\
\hline D3Mit339 & 29.25 & D8Mit321 & 59 & D15Mit43 & 58.01 \\
\hline D3Mit199 & 56.1 & D8Mit280 & 72 & D16Mit165 & 11.17 \\
\hline D3Mit258 & 70.3 & D9Mit224 & 17 & D16Mit63 & 30.76 \\
\hline D3Mit19 & 87.6 & D9Mit162 & 30 & D16Mit189 & 55.2 \\
\hline D4Mit111 & 21.9 & D9Mit214 & 58.79 & D16Mit86 & 66 \\
\hline D4Mit111 & 21.9 & D10Mit206 & 4.47 & D16Mit106 & 71 \\
\hline D4Mit58 & 40.62 & D10Mit3 & 23 & D17Mit238 & 2.22 \\
\hline D4Mit354 & 71 & D10Mit194 & 29 & D17Mit126 & 21.8 \\
\hline D4Mit 234 & 71 & D10Mit180 & 65.22 & D17Mit155 & 50.71 \\
\hline D4Mit42 & 81 & D11Mit71 & 0 & D18Mit64 & 2 \\
\hline D5Mit345 & 1 & D11Mit140 & 25.73 & D18Mit37 & 21 \\
\hline D5Mit391 & 18.03 & D11Mit35 & 44.74 & D18Mit50 & 41 \\
\hline D5Mit115 & 40.01 & D11Mit99 & 63.21 & D19Mit59 & 0.5 \\
\hline D5Mit292 & 80 & D12Mit 240 & 3 & D19Mit19 & 26 \\
\hline D6Mit138 & 2.35 & D12Mit69 & 23.88 & D19Mit137 & 55.7 \\
\hline D6Mit268 & 15.6 & D12Mit14 & 37 & & \\
\hline D6Mit323 & 36.5 & $D 12 N d s 2$ & 59 & & \\
\hline
\end{tabular}

Positions are given in cM (MGI). All markers were used for each scan, with the exception of D8Mit321, which was used only for the scan using stapes sums of 2 or 3 (Fig. 7a) 
Data analysis

Statistical tests were performed using an unpaired twotailed $t$ test, with $P<0.05$ considered significant. A regression analysis was carried out to compare stapes score versus pinna size; $P<0.05$ was considered significant. Normality, linearity, and homoscedasticity were tested to ensure accuracy of the regression. The Shapiro-Wilks test was used to assess the normality of the distributions of the sums of the stapes scores of mice carrying C57BL/6J DNA from the father and from the mother.

\section{Results}

Hush puppy mutants carry a mutation in the $F g f r l$ gene

DNA was extracted from three wild-type and four heterozygous animals. Primers were designed to amplify each exon of Fgfrl. Analysis of the sequence revealed a singlepoint mutation, T2128A, in exon 15 that was consistently found in all heterozygotes examined (Fig. 1a). This nucleotide change leads to a substitution in the amino acid sequence such that the tryptophan residue at position 691 is replaced by arginine (W691R). This missense mutation occurs in a region of the Fgfr1 protein that is highly conserved across species orthologues, and also across the family of Fgfrs (Fig. 1b).

Homozygous hush puppy mutants die at approximately E8.5

Once the mutated gene had been identified, it was possible to study the effects of the mutation on the protein. Previous studies have shown that overexpression of Fgfr1 leads to anteroposterior patterning defects such as additional digits (Hajihosseini et al. 2004). Conversely, Fgfrl-null mice die early in gastrulation, at approximately E8.5 (Deng et al. 1994; Yamaguchi et al. 1994). The homozygote hush puppy phenotype was examined to determine if any of the previously reported phenotypes could be identified. No homozygous animals were present from 56 live births from heterozygote $\times$ heterozygote matings, indicating that the embryos died during gestation. Embryos were examined at a range of ages to determine at what stage homozygotes died. No live homozygous animals were detected at E18.5 $(0 / 15)$, E14.5 (0/18), or E10.5 (0/18), although three homozygous embryos in the process of resorption were found at E10.5. At E8.5 homozygous embryos were detected by sequence analysis, and they were distinguished from littermates by being developmentally retarded, with a
A

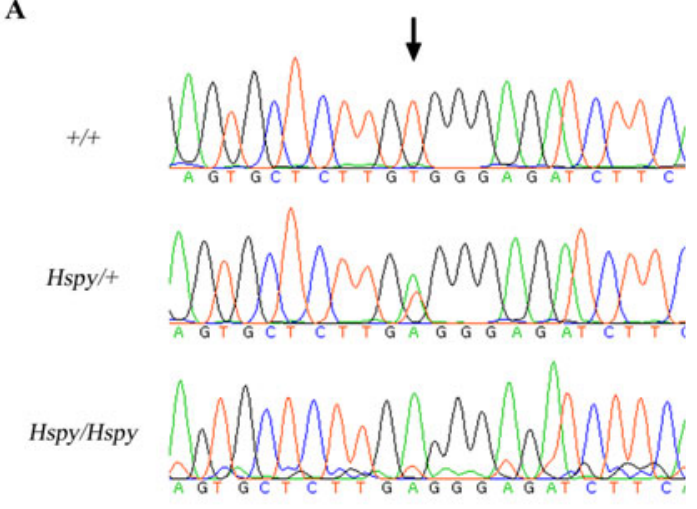

B
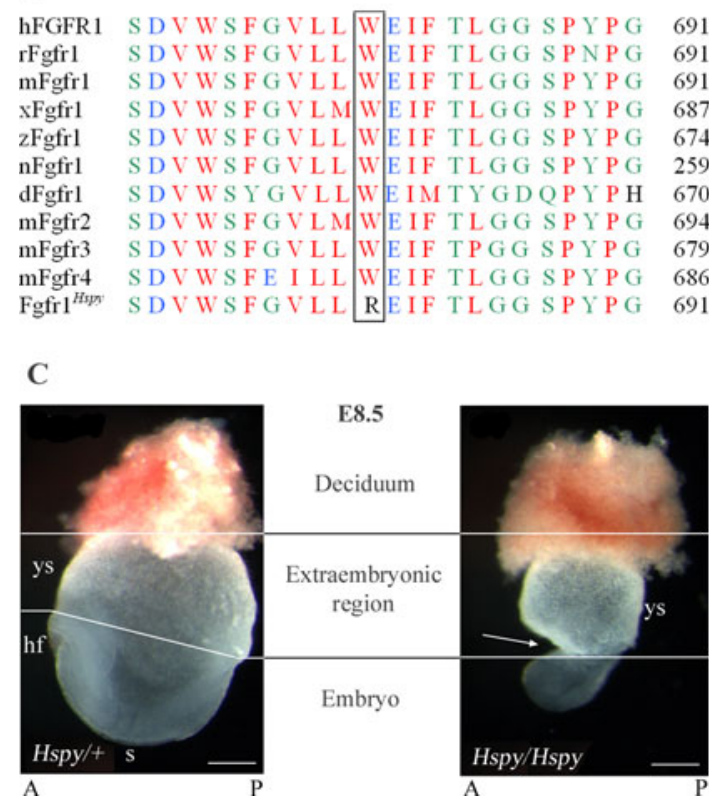

Fig. 1 The hush puppy phenotype is caused by a mutation in Fgfrl. a Fgfrl sequence showing the point mutation T2128A (arrow), located in exon 15 of the gene. Sequences from wild-type animals (top), heterozygotes (middle), and homozygotes (bottom) are shown. b The point mutation causes the missense mutation W691R in a highly conserved tyrosine kinase motif, subdomain IX (complete domain shown). Numbers shown are the residue number for the equivalent amino acid in each sequence. c Development of homozygous embryos is arrested at $\sim$ E8.5. Mutant embryos (E8.5) show a characteristic restriction at the embryonic/extra-embryonic boundary (arrow). Heterozygous embryos have no phenotype at this stage. Scale bar $=250 \mu \mathrm{m}$. $h$ human, $r$ rat, $m$ mouse, $x$ Xenopus, $z$ zebrafish, $n$ Eastern newt, $d$ Drosophila, ys yolk sac, $h f$ head fold, $s$ somites, $A$ anterior, $P$ posterior

restriction at the embryonic/extra-embryonic boundary (Fig. 1c). In E7.5 embryos the restriction was evident in most cases, although in some it was not as obvious. This phenotype was the same as previously reported in Fgfrlknockout mice (Deng et al. 1994; Yamaguchi et al. 1994), supporting the suggestion that the W691R mutation in Fgfr1 is responsible for the phenotype in hush puppy mice. 
The mutation does not prevent transcription of Fgfrl

The next question was whether the gene was transcribed properly. Messenger RNA was extracted from embryos at E7.5, the stage at which mutants were found to still be viable but were generally identifiable due to their phenotype. It was found that cDNA was present for animals both heterozygous and homozygous for the mutation (Fig. 2a). $\beta$-actin was used as an internal control to compare levels of expression between samples. The transcript level of Fgfrl was normalised relative to $\beta$-actin within each genotype group (Fig. 2b). The relative cDNA levels of $F g f r l$ were as follows: wild-type, $1.15 \pm 0.2$ ( $n=3$ animals); heterozygote, $0.49 \pm 0.1 \quad(n=7$ animals $)$; and homozygotes, $0.23 \pm 0.1 \quad(n=8$ animals $)$. There was a significant reduction in Fgfrl transcript levels compared to wild-type in both heterozygotes $(42.6 \%$ of wild-type levels, $P<0.05)$ and homozygotes (20\% of wild-type levels, $P<0.001)$. It has been shown that hypomorphs with reduced transcript levels of only $10 \%$ of normal levels die neonatally (Partanen et al. 1998; Pirvola et al. 2002), suggesting that the reduction in transcript levels in hush puppy homozygotes is unlikely to be sufficient to cause death at an early stage (i.e., E8.5), although different genetic backgrounds of the hypomorphs and the hush puppy homozygotes could influence the time of death.

\section{Construct generation}

In order to study the mutation in $F g f r l$ further, a construct of the mutated receptor was generated. Three clones were created for study: a clone matching the sequence of $\mathrm{Fgfrl}$ DNA from wild-type $\mathrm{C} 3 \mathrm{HeB} / \mathrm{FeJ}$ animals, $F g f r l^{W T}$; the

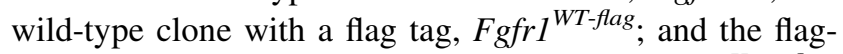
tagged clone with the hush puppy mutation, $F g f r l^{\text {Hspy-flag }}$. These constructs were transiently expressed in human embryonic kidney (HEK293) cells for further study of the function of the mutated receptor.

Fgfr $1^{\text {Hspy }}$ protein is localised at the cell membrane

To analyse whether Fgfr $1^{H s p y}$ was localised normally, the expression pattern was examined by immunocytochemistry. It was possible that if the mutation caused a disruption in the tertiary structure of the protein, it may not be expressed at the cell membrane due to processing or trafficking errors. HEK293 cells were transiently transfected with either $F g f r I^{\text {WT-flag }}$ or $F g f r 1^{\text {Hspy-flag }}$. Immunocytochemistry using an anti-flag FITC-conjugated antibody demonstrated that both the wild-type and the mutated receptor were expressed at the cell membrane $(n=3$ experiments; Fig. 3). This indicates that the mutation in Fgfrl does not prevent translation of the protein and also
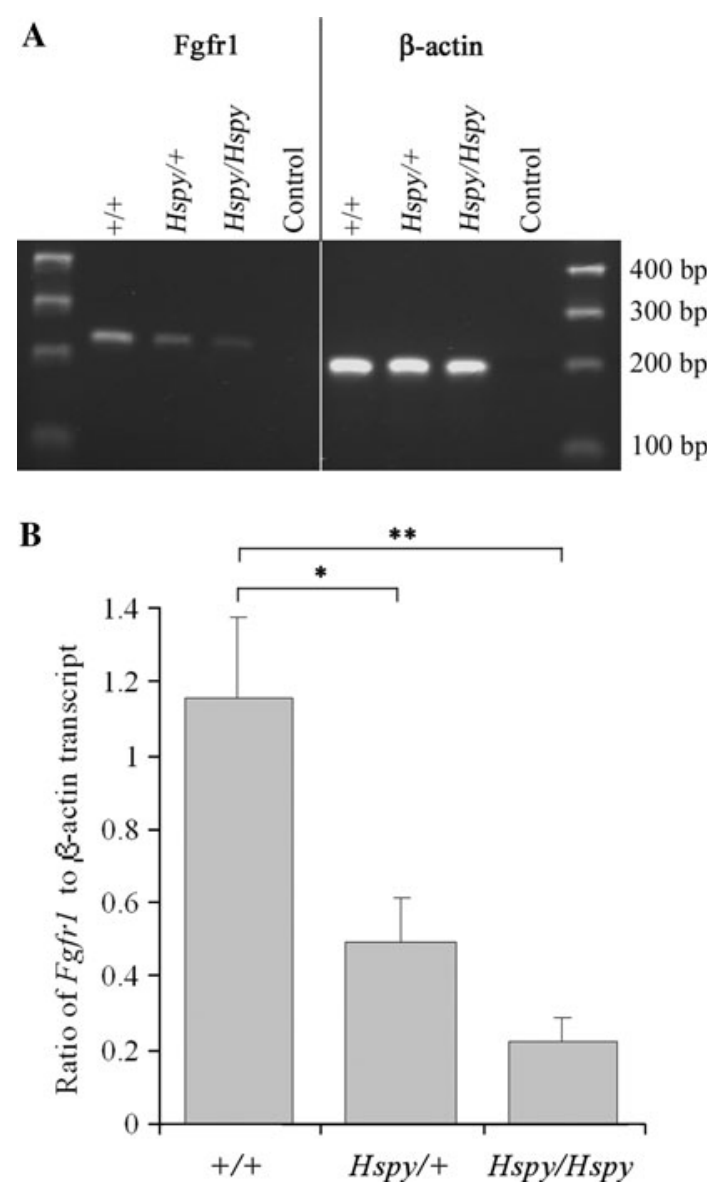

Fig. 2 Reverse transcription PCR of mRNA (E7.5) from each genotype. The results show that the mutation caused a reduction in the amount of transcript present. a PCR products for wild-type $(+/+$, $n=3$ animals), heterozygote (Hspy/+, $n=7$ animals), and homozygote (Hspy/Hspy, $n=8$ animals) are shown for both Fgfrl and $\beta$ actin, the internal control. Control used water in place of cDNA to check for contamination. bp, base pairs. b Levels of Fgfrl transcript per genotype, normalised to $\beta$-actin transcript. $F g f r l$ transcript is significantly reduced compared to wild-type in heterozygotes $(P<0.05)$ and homozygotes $(P<0.001)$

does not affect the trafficking of the receptor to the membrane. This in turn indicates that the effect of the mutation is likely to be a functional one.

The mutation prevents mobilisation of intracellular calcium

Activated Fgfr1 interacts with the phospholipase $\mathrm{C} \gamma$ (PLC $\gamma$ ) pathway, leading to production of $\mathrm{IP}_{3}$, which in turn causes an increase in intracellular calcium ion concentration $\left(\left[\mathrm{Ca}^{2+}\right]_{\mathrm{i}}\right)$. Changes in $\left[\mathrm{Ca}^{2+}\right]_{\mathrm{i}}$ were examined in response to stimulation with FGF1 and heparin (heparin is an accessory molecule that facilitates Fgf binding to Fgfrs) (Kan et al. 1993; Nance 2003; Rapraeger et al. 1991). A subsequent application of CCh $(1 \mathrm{mM})$ was used to ensure cell viability. $\mathrm{CCh}$ is an agonist of muscarinic 

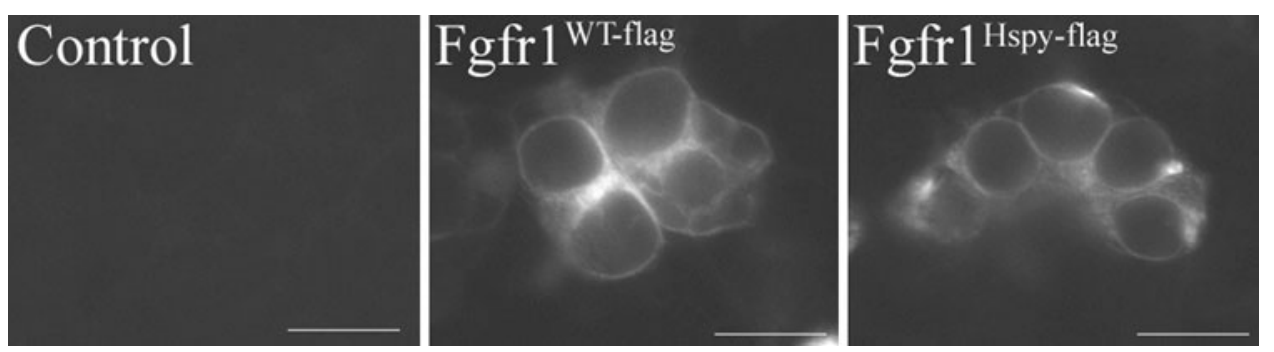

Fig. 3 Fgfr $1^{\text {Hspy-flag }}$ is expressed at the cell membrane. Immunocytochemistry using an anti-flag FITC-conjugated antibody showed that the protein is localised to the cell membrane in cells expressing either Fgfr $1^{\text {WT-flag }}$ or Fgfr $1^{\text {Hspy-flag }}$ ( $n=3$ experiments). Scale bar $=20 \mu \mathrm{m}$

acetylcholine receptors (mAchR), which are endogenously expressed in HEK293 cells. Cells that did not have a CCh response were discounted as it was assumed they lacked a functional $\mathrm{Ca}^{2+}$ store or were unhealthy. Nontransfected cells did not respond to FGF1, confirming that there was no endogenous expression of Fgfr1 in the cells ( $n=194$ cells; Fig. 4a, Table 3). Cells expressing either Fgfr $1^{W T}$ or Fgfr $1^{\text {WT-flag }}$ showed an increase in $\left[\mathrm{Ca}^{2+}\right]_{\mathrm{i}}$ on application of FGF1 and heparin. There was no difference in the number of cells that responded to FGF1 application between cells expressing Fgfr1 ${ }^{W T}(90 / 194)$ and Fgfr1 ${ }^{W T-f l a g}$ (90/189; Table 3). However, there was a small reduction in the amplitude of the response to FGF1 in cells expressing Fgfr1 $1^{\text {WT-flag }}$ compared to Fgfr1 ${ }^{W T}(134 \pm 8.9$ and $177.5 \pm 12 \mathrm{nM}$, respectively; Table 3, Fig. 4b, c). This could be due to lower levels of expression of the construct within cells, or a slightly reduced ability to respond to agonist caused by the presence of the flag tag. Because the introduction of the flag tag did not cause large changes, Fgfr1 ${ }^{\text {Hspy-flag }}$ was examined for functional activity. Cells expressing Fgfr1 ${ }^{\text {Hspy-flag }}$ showed no rise in $\left[\mathrm{Ca}^{2+}\right]_{\mathrm{i}}$ when stimulated with FGF1 and heparin (0/376; Table 3, Fig. 4d). The same cells all responded to CCh $(1 \mathrm{mM})$, confirming that lack of response to FGF1 was not due to cell death. In cells expressing Fgfr $1^{W T}$ or Fgfr $1^{W T-f l a g}$, the responses to $\mathrm{CCh}$ were of significantly reduced amplitude compared to the responses in nontransfected or Fgfr $1^{H s p y-}$ ${ }^{\text {flag }}$-expressing cells. This is most likely due to the cells being unable to refill their intracellular $\mathrm{Ca}^{2+}$ stores sufficiently between agonist applications, resulting in a smaller response to the second agonist, i.e., CCh. The mean transfection efficiency of the $F g f r l^{W T}$ and $F g f r l^{W T-f l a g}$ cells was $47 \%$, and a similar transfection efficiency might be expected with $F g f r l^{H s p y-f l a g}$. Counts of transfected cells in immunocytochemistry experiments showed that there were equal levels of transfection between Fgfr $1^{\text {WT-flag }}$ and Fgfr1 $1^{\text {Hspy-flag }}$ constructs (data not shown). In the $\mathrm{Ca}^{2+}$ imaging experiments, of the 376 cells tested with FGF1, 177 would be expected to be expressing Fgfr $1^{\text {Hspy-flag }}$. The lack of response in any cells demonstrated that $\mathrm{Fgfr} 1^{\text {Hspy-flag }}$ was unable to stimulate the release of intracellular $\mathrm{Ca}^{2+}$. This could be due to an inability to activate the PLC $\gamma$ pathway, which may occur if the receptor's ability to phosphorylate was impaired.

The MAP kinase pathway is not activated by Fgfr1 $1^{\text {Hspy-flag }}$

Another pathway with which activated Fgfr1 interacts is the MAPK pathway, leading to phosphorylation of MAPK proteins. In order to determine whether the mutated receptor could interact with this pathway, levels of phosphorylated MAPK (phospho-MAPK) under both normal unstimulated and FGF-stimulated conditions were examined by Western blotting ( $n=5$ lysates; Fig. 5 ). To compensate for low levels of phospho-MAPK in nontransfected cells, total MAPK was measured in each lysate and phospho-MAPK was then normalised to MAPK levels. It was found that there was a significant difference in levels of phospho-MAPK in nontransfected cells and cells expressing Fgfr1 ${ }^{\text {WT-flag }}(0.58 \pm 0.23$ and $2.17 \pm 0.48$, respectively). The amount of phosphorylation in Fgfr $1^{\text {Hspy-flag }}$. expressing cells was not significantly different than that of nontransfected cells $(0.70 \pm 0.32)$. This indicates that the mutated receptor is not capable of activating the MAPK pathway, which could be expected if the mutated receptor had lost its ability to phosphorylate.

\section{Mapping a hush puppy modifier, Mhspy}

We observed that the hush puppy phenotype is greatly reduced when crossed to a $\mathrm{C} 57 \mathrm{BL} / 6 \mathrm{~J}$ background, suggesting that there may be modifiers of Fgf signalling in the C57BL/6J genome (Table 4). Accordingly, hush puppy mice were outcrossed to $\mathrm{C} 57 \mathrm{BL} / 6 \mathrm{~J}$, then offspring from that cross carrying the Hspy mutation were backcrossed to $\mathrm{C} 3 \mathrm{HeB} / \mathrm{FeJ}$. The heterozygote offspring from the backcross were examined for stapes defects, pinna size, and skull size. A range of phenotypes was found for the features examined (See Supplementary Figs.) so we analysed mice at the two extremes for each measure. Linkage analysis was carried out comparing those mice with the 

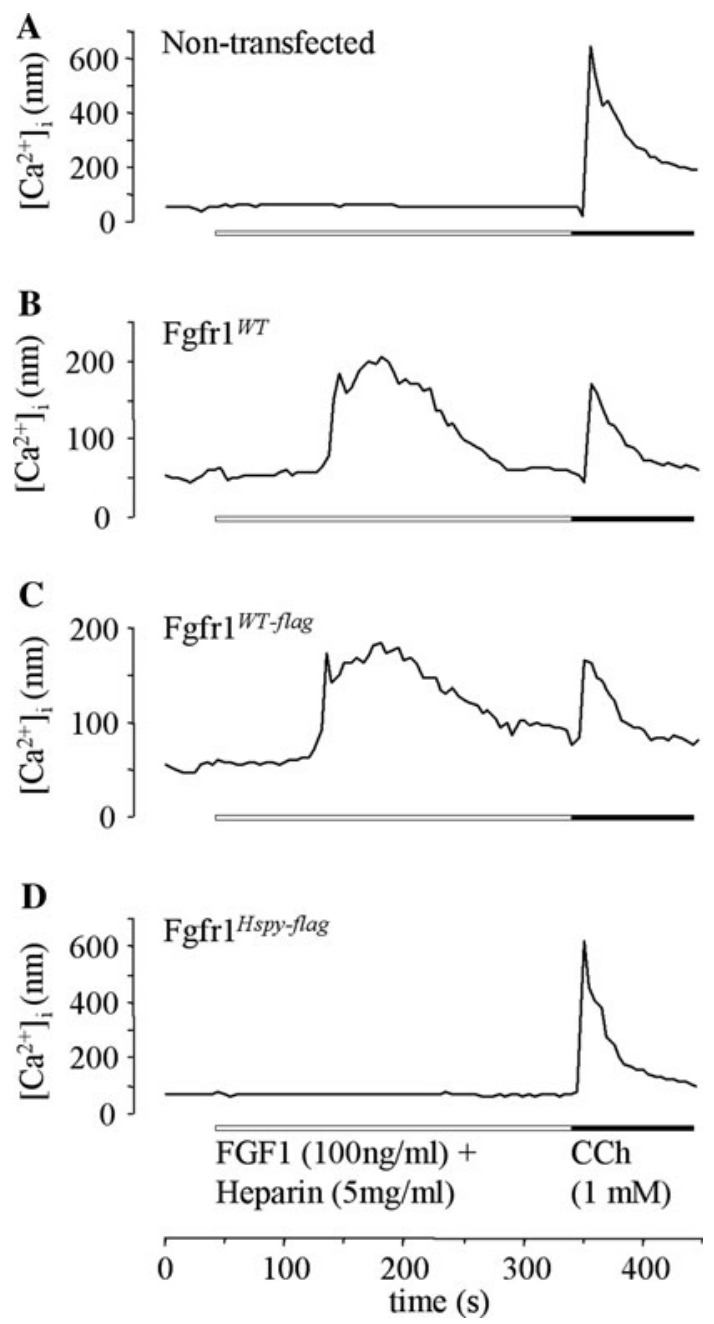

Fig. 4 Changes in $\left[\mathrm{Ca}^{2+}\right]_{\mathrm{i}}$ in response to FGF1. Example traces are shown of changes in $\left[\mathrm{Ca}^{2+}\right]_{i}$ when FGF1 $(100 \mathrm{ng} / \mathrm{ml})$ with heparin $(5 \mathrm{mg} / \mathrm{ml})$ is applied to the cells, followed by application of CCh $\left(1 \mathrm{mM}\right.$, to ensure functional $\mathrm{Ca}^{2+}$ stores are present in the cells). a There is no response to FGF1 in nontransfected cells $(n=194$ cells). b Cells expressing Fgfr $1^{W T}$ give a transient increase in $\left[\mathrm{Ca}^{2+}\right]_{i}$ on application of FGF1 ( $n=194$ cells). c Addition of the flag tag to the receptor $\left(\mathrm{Fgfr} 1^{\text {WT-flag }}\right)$ causes a small reduction in the amplitude of the FGF1 response ( $n=189$ cells). d Cells expressing Fgfr $1^{\text {Hspy-flag }}$ gave no increase in $\left[\mathrm{Ca}^{2+}\right]_{\mathrm{i}}$ in response to FGF1 ( $n=376$ cells)

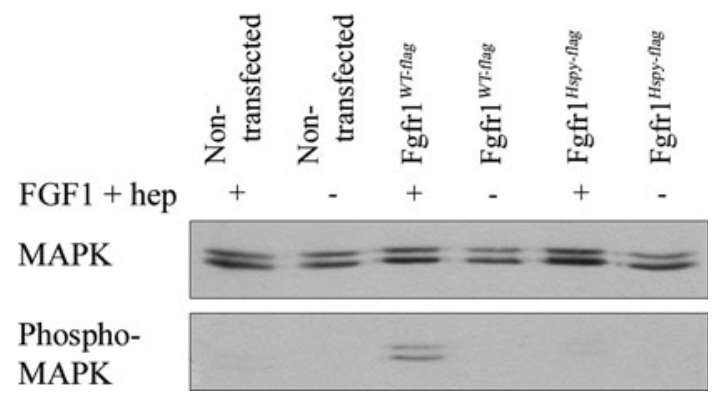

Fig. 5 The hush puppy mutation prevents phosphorylation of MAP kinase. Cells were stimulated with $100 \mathrm{ng} / \mathrm{ml} \mathrm{FGF1} \mathrm{and} 5 \mathrm{mg} / \mathrm{ml}$ heparin and then examined for MAPK expression and phosphorylation via Western blotting ( $n=5$ lysates). The top blot shows total MAP kinase in the cell lysates. The bottom blot indicates the amount of MAP kinase that is phosphorylated when stimulated. There was no significant difference between cells expressing Fgfr1 ${ }^{\text {Hspy-flag }}$ and nontransfected cells. + , stimulated cells; - , unstimulated cells

most normal appearance (the most modified) to those mice with the most affected phenotype (the least modified). There was no evidence from the distribution of phenotypes for any X-linked modifier (data not shown).

Stapes were given a score from 1 to 8 , depending on their appearance (Fig. 6, Supplementary Fig. 1) Mice used for linkage analysis were those with a score of 3 or less for left and right ears combined (Fig. 7a), and mice with a combined score of 10 or more (Fig. 7b). Only animals with scores available for both ears were used. A notable increase in heterozygosity to over $80 \%$ was observed at the distal end of chromosome 7 (markers D7Mit66, D7Mit105, and D7Mit259) in the most modified animals. Conversely, a decrease in heterozygosity was observed in the same location in the least modified animals. The low level of heterozygosity on proximal chromosome 8 corresponds with the location of the Fgfrl gene, which was selected for carrying the $\mathrm{C} 3 \mathrm{HeB} / \mathrm{FeJ}$-derived Hspy mutation.

Pinna size was measured at two ages: 5-8 weeks and 7.5-8 months (Supplementary Figs. 2 and 3). The animals used for linkage analysis were those with a combined

Table 3 Percent and amplitude of $\left[\mathrm{Ca}^{2+}\right]_{i}$ responses in cells expressing Fgfr1 constructs

\begin{tabular}{|c|c|c|c|c|c|}
\hline & \multirow[t]{2}{*}{ No. of cells } & \multicolumn{2}{|c|}{ FGF1 $(100 \mathrm{ng} / \mathrm{ml})+$ heparin $(5 \mu \mathrm{g} / \mathrm{ml})$} & \multicolumn{2}{|c|}{ Carbachol $(1 \mathrm{mM})$} \\
\hline & & $\%$ responding & Change in $\left[\mathrm{Ca}^{2+}\right]_{\mathrm{i}}(\mathrm{nM})$ & \% responding & Change in $\left[\mathrm{Ca}^{2+}\right]_{\mathrm{i}}(\mathrm{nM})$ \\
\hline Nontransfected & 194 & 0 & $0 \pm 0$ & 100 & $604 \pm 25$ \\
\hline Fgfr $1^{W T}$ & 194 & 46.4 & $178 \pm 12^{\mathrm{a}}$ & 100 & $78 \pm 7^{\mathrm{a}, \mathrm{b}}$ \\
\hline Fgfr $1^{W T-f l a g}$ & 189 & 47.6 & $134 \pm 9^{\mathrm{a}}$ & 100 & $97 \pm 11^{\mathrm{a}, \mathrm{b}}$ \\
\hline Fgfr $1^{\text {Hspy-flag }}$ & 376 & 0 & $0 \pm 0$ & 100 & $561 \pm 21$ \\
\hline
\end{tabular}

a There was a significant difference in amplitude of $\left[\mathrm{Ca}^{2+}\right]_{\mathrm{i}}$ change between $\mathrm{Fgfr} 1^{W T}$ and Fgfr1 ${ }^{W T-f l a g}$ in response to FGF1 with heparin, but there was no difference between the CCh responses in these cells. CCh amplitudes are given for only the cells that responded to FGF1

b The response to CCh in cells that gave an FGF1 response was significantly less than in cells that did not respond to FGF1 
Table 4 Correlation of Hspy genotype with ossicle and pinna defects in mice on their original $\mathrm{C} 3 \mathrm{HeB} / \mathrm{FeJ}$ genetic background and in $\mathrm{F} 1 \mathrm{mice}$ from the outcross of $\mathrm{Hspy/+}$ mice on a $\mathrm{C} 3 \mathrm{HeB} / \mathrm{FeJ}$ background to C57BL/6J mice

\begin{tabular}{|c|c|c|c|c|c|c|c|c|}
\hline & \multicolumn{4}{|c|}{$\mathrm{C} 3 \mathrm{HeB} / \mathrm{FeJ}$ (original background) } & \multicolumn{4}{|c|}{ F1 mice from $H s p y /+\times$ C57BL/6J cross } \\
\hline & \multicolumn{2}{|l|}{ Wild-type } & \multicolumn{2}{|c|}{ Hush puppy heterozygote } & \multicolumn{2}{|l|}{ Wild-type } & \multicolumn{2}{|c|}{ Hush puppy heterozygote } \\
\hline & Left & Right & Left & Right & Left & Right & Left & Right \\
\hline Pinna shape & $0 \%(0 / 30)$ & $0 \%(0 / 30)$ & $73.9 \%(17 / 23)$ & $65.2 \%(15 / 23)$ & $0 \%(0 / 36)$ & $0 \%(0 / 36)$ & $6.5 \%(2 / 31)^{\mathrm{a}}$ & $6.5 \%(2 / 31)^{2}$ \\
\hline Malleus & $0 \%(0 / 11)$ & $0 \%(0 / 11)$ & $0 \%(0 / 13)$ & $0 \%(0 / 12)$ & $0 \%(0 / 36)$ & $0 \%(0 / 36)$ & $0 \%(0 / 30)$ & $0 \%(0 / 31)$ \\
\hline Incus & $0 \%(0 / 36)$ & $0 \%(0 / 37)$ & $21.4 \%(6 / 29)$ & $14.8 \%(4 / 28)$ & $0 \%(0 / 36)$ & $0 \%(0 / 35)$ & $0 \%(0 / 31)$ & $0 \%(0 / 29)$ \\
\hline Stapes & $0 \%(0 / 34)$ & $0 \%(0 / 37)$ & $96.4 \%(27 / 28)$ & $100 \%(27 / 27)$ & $0 \%(0 / 36)$ & $0 \%(0 / 35)$ & $0 \%(0 / 31)$ & $3.6 \%^{\mathrm{b}}(1 / 28)$ \\
\hline
\end{tabular}

Results shown are the percentage of animals with abnormalities, with the number of animals with the defect and number examined in parentheses. Preyer reflex results are not shown; abnormal pinnae often do not flick back when exposed to a click, so the test is not conclusive in these animals. No defects were found in wild-type animals on either background. On the $\mathrm{C} 3 \mathrm{HeB} / \mathrm{FeJ}$ background, a single heterozygote animal was found to have a unilateral stapes defect, but all other heterozygotes had bilateral stapes malformations

a,b The single stapes defect observed in the F1 mice was found in an animal with an ipsilateral pinna defect

surface area of both pinnae of 80 units or more (the most modified; Supplementary Fig. 4A) and those with a combined surface area of 60 units or less (the least modified; Supplementary Fig. 4B) from the younger age group. As for the stapes abnormalities, an increase of heterozygosity in the most modified animals and a decrease of heterozygosity in the least modified animals was observed at the distal end of chromosome 7.

To determine if the pinna and stapes defects correlated, a regression analysis was carried out, treating left and right sides separately to ensure independence. A significant negative correlation was observed for both sides (Supplementary Fig. 5; left ear: $r=-0.665, n=181, P<2.2 \times 10^{-16}$; right ear: $\mathrm{r}=-0.617, n=182, P<2.2 \times 10^{-16}$ ).

Distal chromosome 7 is subject to imprinting, so we asked whether the putative C57BL/6J-derived modifier might be among the imprinted loci by looking for any skew in the degree of modification of the stapes or pinna phenotype associated with inheriting the modifier from the mother or from the father. We replotted the numbers of mice in each category for the stapes defect and for pinna size according to whether the most distal chromosome 7 marker (D7Mit259) from the C57BL/6J parent was inherited from the maternal or the paternal line. For the pinna size, there was no evidence of any difference in distribution (data not shown). However, for the stapes defect, there was a marked skew in the distribution toward the more modified (least abnormal) end of the distribution when the C57BL/6J marker was inherited from the paternal line, but there was no skew when it was inherited from the mother (Fig. 8). This skew suggests that there may be imprinting of the modifier. For example, the allele derived from the maternal line might be inactivated by imprinting while the allele derived from the paternal line may show no imprinting and hence may be active in compensating in some way for the Hspy mutation.
The ratio of the skull length (nasal bone to interparietal bone) to the skull width (measured along the suture of the parietal bone) was used to determine which animals had been most modified (length:width ratio $>2.08$ ) and least modified (length:width ratio $<2$ ) (Supplementary Fig. 6A, B). DNA from these animals was used for linkage analysis (Supplementary Figs. 7 and 8). In addition, a small proportion of mice had a marked bend in their nose (measured by deviation from the midline of the skull starting at the base of the nasal bone), and linkage analysis was carried out on those with a bend of greater than $10^{\circ}$ (deemed least modified) and those with a bend of less than $2^{\circ}$ (most modified; Supplementary Figs. 6C, D and 9). However, there were no obvious peaks in the genome scans for skull length:width ratio or degree of nasal bend.

\section{Discussion}

In this study we have detected a missense mutation in the tyrosine kinase domain of $\mathrm{Fgfrl}$ leading to a tryptophan-toarginine substitution in the hush puppy mouse mutant. Embryos that were homozygous for the $F g f r l^{H s p y}$ mutation died at gastrulation and demonstrated the same characteristics as Fgfrl-knockout embryos (Deng et al. 1994) in that they die at the same time point, with a restriction at the embryonic/extra-embryonic boundary. The mutated gene was transcribed, although at a lower level than in the wild type, and the protein was correctly processed and trafficked to the cell plasma membrane. The functional effect of the mutation on the receptor was such that the receptor could not activate at least two of its downstream pathways, the Ras/MAP kinase pathway and the PLC $\gamma / \mathrm{IP}_{3}$ pathway. In effect, the mutation caused a loss of function of the receptor. There are several possible explanations of why Fgfr1, with the hush puppy mutation, may not be capable 
Fig. 6 Examples of stapes from the backcross mice, all heterozygotes for the $F g f r 1^{\text {Hspy }}$ mutation. a The most modified stapes. Both crura appear relatively normal (score 1). b Stapes with thinner than normal posterior crus (score 2). c Posterior crus is quite thin in the middle and may be lacking bone in the centre (score 3). d Posterior crus lacks bone in the middle but tissue is still present forming a very thin link (score 4). e Posterior crus is missing but the stapedial muscle attachment is present at the top right (score 5). f Posterior crus is missing, including the stapedial muscle attachment but anterior crus appears normal (score 6). g Posterior crus completely missing. Anterior crus is affected and appears thin and often more widely splayed than normal (score 7). h Stapes is bony through area between crura. The stapedial artery did not pass through the stapes (score 8). This feature was rarely seen ( $n=4$ ears), and as it appeared to be qualitatively different to the other stapes defects, it was not included in subsequent analyses. i Diagram to illustrate the backcross used to map the modifier
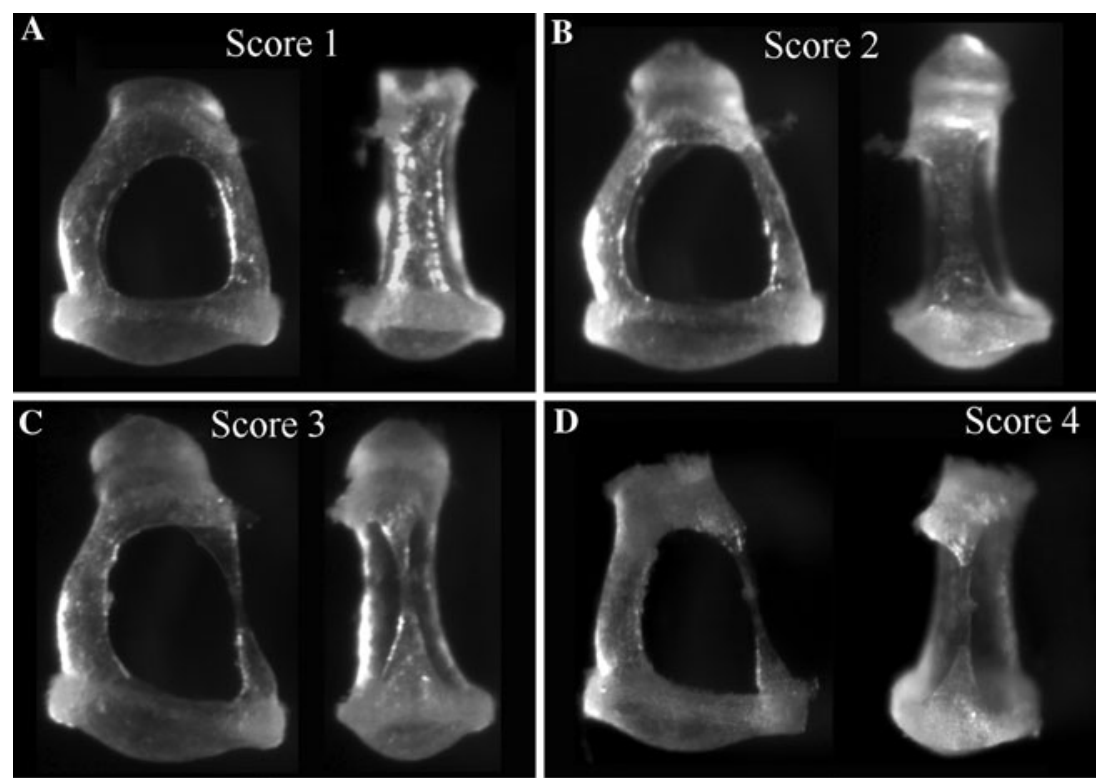

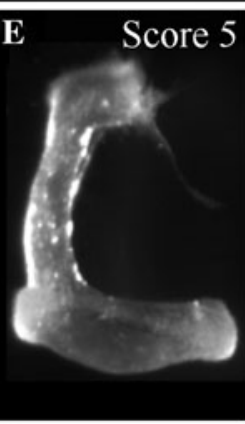

I

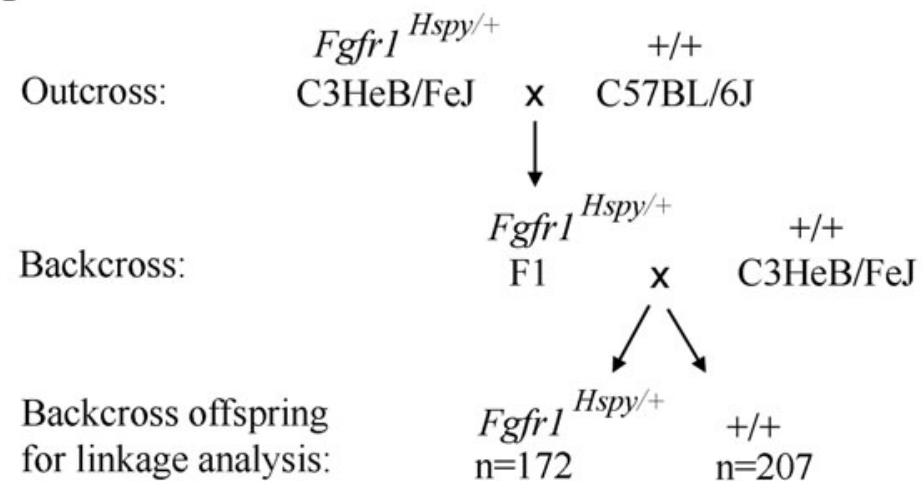

of activating its signalling pathways: (1) the mutation may prevent interaction with FGF1, (2) once stimulated, the mutated receptor may be unable to dimerise and autophosphorylate, and (3) the mutated receptor may be unable to phosphorylate its target proteins. Due to the location of the mutation in the tyrosine kinase domain, it is most likely that either or both of the last two hypotheses account for the phenotype.

Tyrosine kinases have 11 conserved domains in their catalytic region, with the greatest degree of conservation occurring in subdomains VI-IX (Hanks et al. 1988). The hush puppy mutation in Fgfrl occurs in the middle of subdomain IX, conserved in the majority of tyrosine kinase receptors, including all four isoforms of the Fgfr family, and for the Fgfr1 isoform it is conserved from zebrafish to human. In the hush puppy mutant, a tryptophan residue (a hydrophobic amino acid) located at the end of an alpha helix (Mohammadi et al. 1996) is replaced by an arginine, a smaller hydrophilic residue, and is likely to cause disruption to the secondary structure of this region. Such a model had been proposed previously for a tyrosine kinase receptor, the insulin receptor, with a similar mutation. The 
Fig. 7 Genome scans using the sum of the stapes defect scores from both left and right ears. a Polymorphic microsatellite markers (Table 2) were used on the DNA of animals that had a combined left and right score of 2 or 3 . These are therefore the most modified mice from the backcross ( $n=39$ animals). b Polymorphic microsatellite markers (Table 2) were used on the DNA of animals that had a combined left and right score of 10 or more. These are therefore the most abnormal (least modified) mice from the backcross ( $n=36$ animals). Mice with a solid bony stapes (Fig. 6H, score 8 on either side; $n=4$ ) were not included in the genome scan

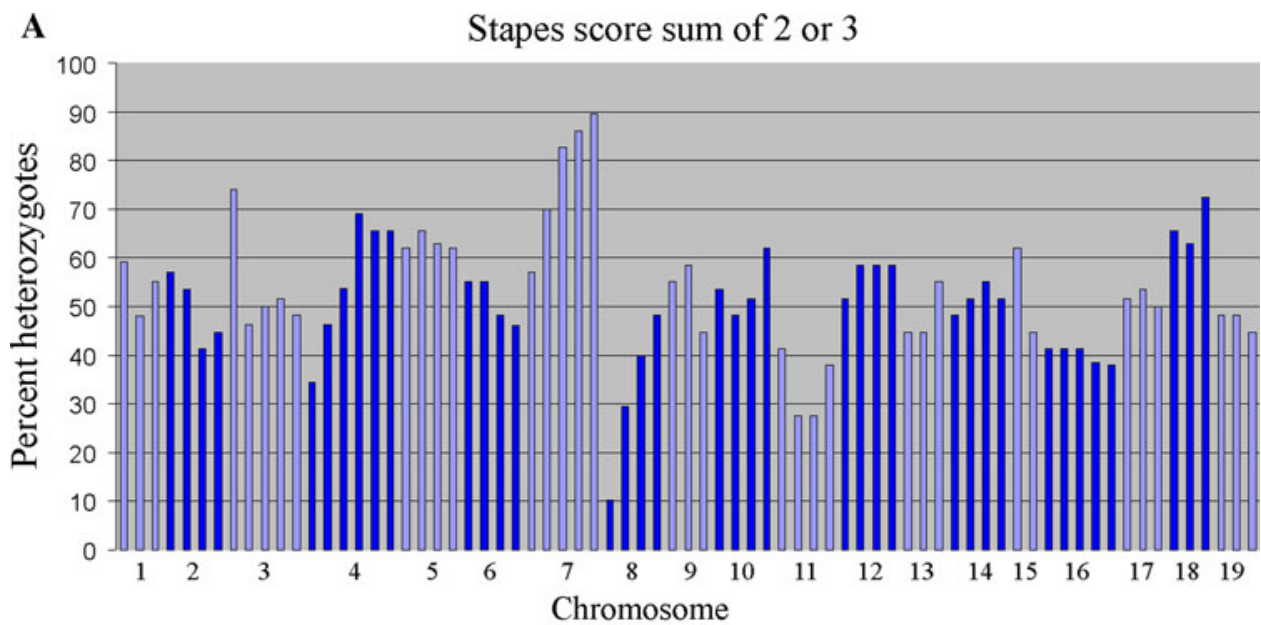

B

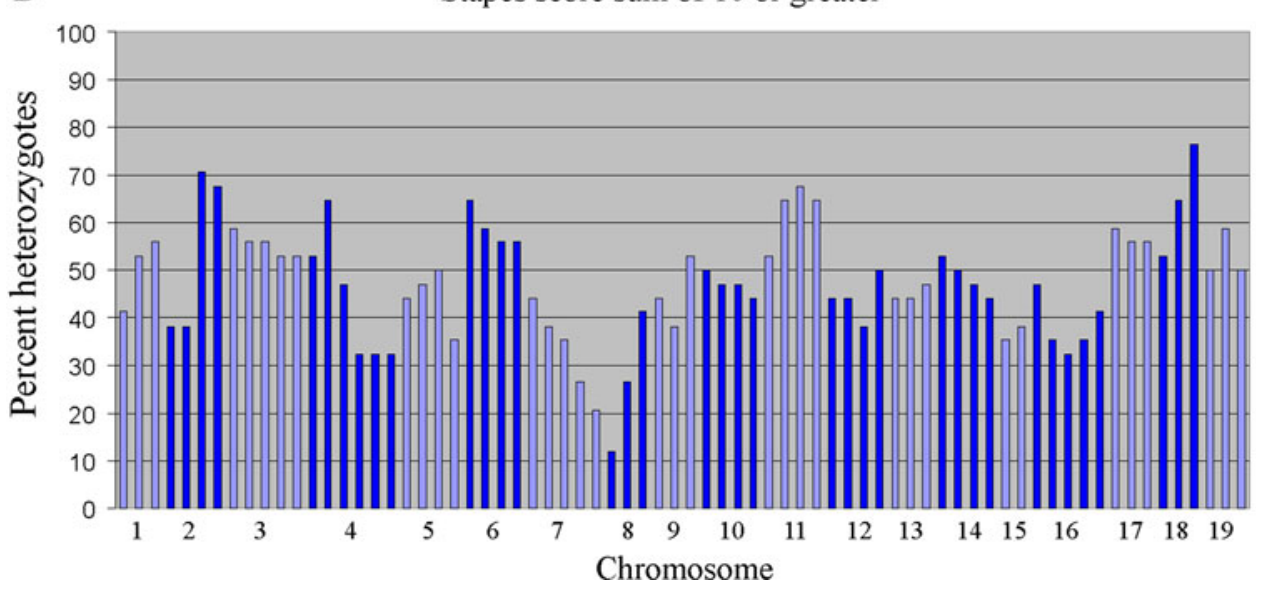

Distribution of the sum of the stapes scores for mice carrying distal chromosome 7 C57BL6/J DNA from the father ( $\square$ ) and from the mother ( $\square$ ).

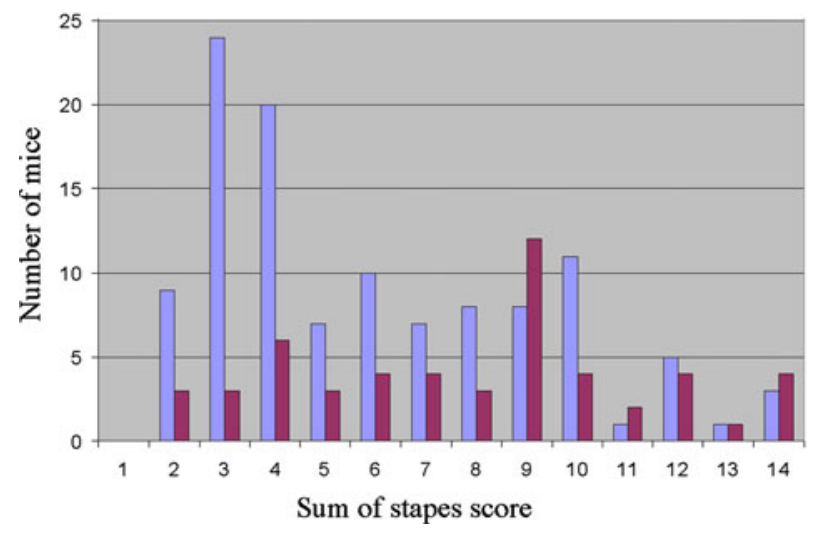

Fig. 8 The distribution of the sum of the stapes scores for mice carrying distal chromosome 7 C57BL/6J DNA (marker D7Mit259) from their father (violet) and for mice carrying distal chromosome 7 C57BL/6J DNA from their mother (maroon). There is a noticeable bias toward the more modified end (scores 2-4) for those mice from a heterozygote father (Shapiro-Wilks test score for mice from a heterozygote father: $6.85 \times 10^{-7}$; score for mice from a heterozygote mother: 0.0501) tryptophan residue in the same location in subdomain IX in the insulin receptor (W1227, Supplementary Fig. 10; originally referred to as W1200S) was found to be mutated to serine in a heterozygous female patient with non-insulindependent diabetes mellitus, polycystic ovarian disease, and acanthosis nigricans (Grigorescu et al. 1986; Moller and Flier 1988). Insulin receptors with the W1227S mutation were noted to have a $70 \%$ impairment of receptor autophosphorylation when stimulated and were unable to catalyse tyrosyl phosphorylation of substrate proteins (Grigorescu et al. 1986; Moller et al. 1990). It was proposed that the mutation may destabilize the hydrophobic packing of the C-terminal lobe due to the inclusion of the hydrophilic substitute residue, in turn affecting the tyrosine kinase function (Hubbard et al. 1994). As both the insulin receptor and Fgfrl mutations have similar hydrophilic substitutions at the same location, this destabilisation effect may also occur in Fgfr1 in the hush puppy mutant. In another example, dominantly inherited CATSHL syndrome (camptodactyly, tall stature, and hearing loss) is associated with a histidine-to-arginine missense mutation in the 
tyrosine kinase domain of FGFR3, although no defects of the middle ear were detected in affected individuals (Toydemir et al. 2006).

The hush puppy mutation leads to dominant inheritance of pinna and ossicle malformations, skull anomalies, reduced rows of cochlear hair cells, and raised thresholds for auditory responses in heterozygous animals (Pau et al. 2005). Previous reports of other Fgfr1 mutations have not mentioned dominant inheritance of any of these features (Deng et al. 1994; Yamaguchi et al. 1994), although other dominant effects such as a low penetrance of posterior vertebral transformations in heterozygotes for the Y766F mutation have been reported (Partanen et al. 1998). Pinna and ossicle defects were reported in mice homozygous for hypomorphic mutations that reduced Fgfr1 levels to 10-20\% (Partanen et al. 1998), suggesting that the developing embryo is sensitive to receptor level. The hush puppy mutation may have a dominant effect by reducing in some way wild-type Fgfr1 protein to less than the predicted $50 \%$ of normal levels in heterozygotes, or the mutant protein may interact with wildtype protein in a way that reduces its activity. For example, if a mutant receptor dimerised with a wild-type receptor, it may inhibit activity of the wild-type Fgfr1 partner, reducing effective activity to the predicted $25 \%$ of dimers containing only wild-type receptor. Alternatively, mutant protein may influence the kinetics of the receptor and/or dimer. Other mutations in human FGFRl have previously been suggested to act in a dominant negative manner in Kallmann syndrome (Dode et al. 2003; Pitteloud et al. 2006).

The pinna and the middle ear ossicles are both derived from the same embryological origins, the pharyngeal arches (PA). The pinna develops from several hillocks that arise at the dorsal base of PA1 and PA2. The caudal region of PA1 gives rise to the malleus and the incus, as well as the mandible, while the stapes is derived from PA2 (for review see Mallo 1998). Mutants expressing 10-20\% of normal Fgfr1 levels have been shown to have greatly reduced pinna size at birth (Partanen et al. 1998; Trokovic et al. 2003), coupled with ossicle defects of varying severity, including absence of most ossicles (Trokovic et al. 2003). The Fgfr1 hypomorph with $20 \%$ expression showed a reduction in size of PA2 from E9.5 due to a failure of migration of neural crest cells into the area (Trokovic et al. 2003). It was proposed that Fgfr1 is involved in patterning of the pharyngeal region and plays a permissive role in the migration of neural crest cells into PA2.

A study by Hoch and Soriano (2006) also found defects in PA2 development related to Fgfr1 signalling. One of the proteins that Fgfr1 phosphorylates is fibroblast growth factor receptor substrate 2 (FRS $2 \alpha$ and $-\beta$ ) (Kouhara et al. 1997). FRS 2 activates the Ras/MAP kinase pathway via two routes: (1) recruiting Grb2/Sos complexes, which activate the pathway (Hadari et al. 1998; Kouhara et al.
1997), and (2) binding the protein tyrosine phosphatase Shp2, which in turn activates Grb2 (Hadari et al. 1998, 2001). Embryos with Fgfr1 that lacks the binding site for FRS $2 \alpha$ die during late embryogenesis, with defects in neural tube closure and development of the tail bud (Hoch and Soriano 2006). It was also found that there were defects in the development of the PAs such that PA2 was hypoplastic by E10.5 due to a large reduction in proliferation of the mesenchymal cells. The derivatives of PA2 were selectively affected in mutant embryos, with E15.5 embryos having missing or hypoplastic stapes. Combining the evidence described here, it would seem plausible that patterning defects in PA2 due to a reduction in Fgfr1 signalling cause the hush puppy heterozygous phenotype. The stapes defect could be the result of insufficient FRS $2 \alpha$ activation due to a decrease in functional Fgfr1.

We propose that the missense mutation W691R in the Fgfrl gene is responsible for the phenotypic defects in hush puppy mice for several reasons. Firstly, the gene is located in the nonrecombinant region of chromosome 8 (Pau et al. 2005), and the most penetrant feature (the stapes crura malformation) always segregates with the mutation. Secondly, Fgfrl is known to be expressed widely in the craniofacial region, including structures affected by the mutation (Bachler and Neubüser 2001; Rice et al. 2003). Thirdly, the affected residue is highly conserved and is located in an important functional region, the kinase domain. Fourthly, we have shown that the mutation affects two key roles of the receptor, its ability to activate the $\mathrm{IP}_{3}$ pathway and the RAS/MAP kinase pathway. Finally, the hush puppy mutant has several features in common with known hypomorphic mutations of Fgfrl, such as lethality of the homozygotes at around the time of gastrulation, malformation of the stapes, and pinna defects (Hoch and Soriano 2006; Trokovic et al. 2003).

We found some variation in the phenotype of hush puppy mutants, including asymmetric defects in individual mice. Variability in the phenotype has been reported for other mutations of Fgfrl, and mixed genetic background is known to be a complicating factor influencing penetrance of the abnormalities (Hoch and Soriano 2006). The hush puppy mutation originated and is maintained on an inbred $\mathrm{C} 3 \mathrm{HeB} / \mathrm{FeJ}$ genetic background, indicating that the variability in phenotype most likely is influenced by stochastic events in addition to genetic background effects.

Modifier genes have been found for numerous pathological mutations, including those responsible for deafness, and range from genes affecting transcription or translation, such as $N x f 1$, an RNA export protein that can compensate for large intronic IAP insertions (Floyd et al. 2003), to genes directly involved in the mechanisms affected by the mutation, in either the same pathway or possibly an alternative one such as the modifier of tubby hearing (mothl), which is an allele of 
the neuron-specific gene Mtapla (Ikeda et al. 2002). In the case of hush puppy, the mutation appears to disable the phosphorylation ability of the protein, so a modifier might be expected to compensate for that inability. The stapes and pinna genome scans indicate that a potential modifier (Mhspy) of these aspects of the hush puppy phenotype is located at the distal end of chromosome 7. Interestingly, this region includes $F g f r 2$, another tyrosine kinase receptor known to be expressed in the otic epithelium in a similar way to Fgfrl (Pirvola et al. 2004). The four Fgf receptors have a conserved structure with varying degrees of homology in the different domains [from $21-38 \%$ in the amino-terminal domain to $74-92 \%$ in the tyrosine kinase domain (Partanen et al. 1991)] and can bind multiple FGF ligands (Givol and Yayon 1992; Zhang et al. 2006). Like Fgfrl, mutations in Fgfr2 can lead to Pfeiffer syndrome (Schell et al. 1995). In the process of lens differentiation, Fgfr1, Fgfr2, and Fgfr3 are functionally redundant (Zhao et al. 2006), and in other situations, mutations in $F g f r 2$ allow Fgfr2 to fulfill the role of Fgfr1 where it would otherwise be incapable; for example, Fgfr2 is not normally capable of Fgf1 translocation, but two amino acid changes in the $\mathrm{C}$-terminus enable the protein to do that (Sørensen et al. 2006). Other mutations in $F g f r 2$ have been shown to increase signalling, particularly through affecting FRS (Ahmed et al. 2008; Hatch et al. 2006; Moffa and Ethier 2007), so $F g f r 2$ would be a prime candidate in a search for this modifier. Other genes encoding components of FGF signalling pathways are located on distal chromosome 7 and are also candidates for Mhspy, including Fgf3, Fgf4, and Fgf15. Dusp 8 on distal chromosome 7 may also be a candidate, because a related gene, Dusp6, has been shown to regulate Fgf signalling ( $\mathrm{Li}$ et al. 2007). Comparisons of coding and splice site sequence in these five potential modifier genes between the C57BL/6J reference sequence and $\mathrm{C} 3 \mathrm{H} / \mathrm{HeJ}$ (a related $\mathrm{C} 3 \mathrm{H}$ line) show no obvious differences that might explain the modifier effect observed. However, there are several SNPs that are either synonymous or present in the UTRs of Fgf3, Fgf4, Fgfl5, and Dusp8, and it is possible that these could play a role. We found suggestive evidence that Mhspy may be subject to imprinting, although none of these candidate genes has been reported to be imprinted. We compared the reported C57BL/6J and $\mathrm{C} 3 \mathrm{H} / \mathrm{HeJ}$ sequence for exons, splice sites, and UTRs of genes within or close to the known imprinted clusters on distal chromosome 7 (H19, Igf2, Ins2 in one cluster and Osbp15, Nap1l4, Phlda2, Tssc5/Slc22a18, Cdkn1c, Kcnq1, Kcnqlot1, Tssc4, Cd81, and Ascl2 in the other cluster, plus Cars which is close to imprinted regions). Cars showed one nonsynonymous SNP at position 150745083 (rs13459436), changing a serine to glycine, but no other reliable sequence changes were observed.

Mutations in Fgfrl have been identified in several human syndromes. Pfeiffer syndrome is caused by a variety of mutations in $F g f r l$, causing a range of symptoms such as premature skull fusion, underdevelopment of the midface, defects of the hands and feet, and deafness in $\sim 50 \%$ of cases. However, it is unlikely that the hush puppy mutation is a model of Pfeiffer syndrome because the mutation in this human disease leads to upregulation of receptor function, whereas the hush puppy mutation in $F g f r l$ causes an inactive form of the receptor. Kallmann syndrome can be caused by loss-of-function mutations in FGFR1 (Albuisson et al. 2005; Dode et al. 2003; Pitteloud et al. 2005; Sato et al. 2004). This syndrome is characterised by hypogonadism and anosmia, but unilateral hearing loss has been reported in one individual (Dode et al. 2003). Mice doubly heterozygous for the hush puppy mutation and a nonsense mutation in $C h d 7$ (another gene associated with Kallmann syndrome) show no sign of the Kallmann phenotype, so it would seem unlikely that hush puppy mice could be an animal model for Kallmann syndrome (Bergman et al. 2010). A disease recently attributed to mutations in Fgfrl is osteoglophonic dysplasia, which is characterised by short stature, craniosynostosis, and bone demineralisation. This condition is caused by activating mutations of $\mathrm{Fgfrl}$ in specific extracellular and transmembrane regions of the gene (Supplementary Fig. 11) (White et al. 2005). Although skull defects have been noted in hush puppy heterozygote animals, the hush puppy mutation is unlikely to be a model for this disorder due to the location of the mutation. However, as these examples show, it is only recently that human conditions are being attributed to mutations in FGFRI; therefore, the hush puppy Fgfrl mutant may yet be found to represent a human disorder (Supplementary Fig. 11) (Wilkie 2008).

Acknowledgments We thank Dr. Colin Taylor for assistance with clone generation, Dr. Stephen Tovey for his advice on single-cell calcium imaging, Dr. Erika Bosman for assistance with embryo dissection, Dr. Natasha Karp for help with the regression analysis, Professors Andrew Wilkie and Jo Peters for useful discussion of the data, and Dr. Martin Hrabé de Angelis and Dr. Helmut Fuchs for their initial discovery of the hush puppy mutant. This work was supported by The Wellcome Trust (grant 077189), the MRC, Deafness Research UK, and the EC (CT97-2715 and QLG2-CT-1999-00988). Skarlatos Dedos was supported by a Wellcome Trust programme grant (072084) awarded to Colin Taylor.

Open Access This article is distributed under the terms of the Creative Commons Attribution Noncommercial License which permits any noncommercial use, distribution, and reproduction in any medium, provided the original author(s) and source are credited.

\section{References}

Ahmed Z, Schüller AC, Suhling K, Tregidgo C, Ladbury JE (2008) Extracellular point mutations in FGFR2 elicit unexpected changes in intracellular signalling. Biochem J 413:37-49 
Albuisson J, Pecheux C, Carel JC, Lacombe D, Leheup B, Lapuzina P, Bouchard P, Legius E, Matthijs G, Wasniewska M, Delpech M, Young J, Hardelin JP, Dode C (2005) Kallmann syndrome: 14 novel mutations in KAL1 and FGFR1 (KAL2). Hum Mutat 25:98-99

Bachler M, Neubüser A (2001) Expression of members of the Fgf family and their receptors during midfacial development. Mech Dev 100:313-316

Bergman JEH, Bosman EA, van Ravenswaaij-Arts CMA, Steel KP (2010) Study of smell and reproductive organs in a mouse model for CHARGE syndrome. Eur J Hum Genet 18:171-177

Bonfield JK, Smith K, Staden R (1995) A new DNA sequence assembly program. Nucleic Acids Res 23:4992-4999

Deng CX, Wynshaw-Boris A, Shen MM, Daugherty C, Ornitz DM, Leder P (1994) Murine FGFR-1 is required for early postimplantation growth and axial organization. Genes Dev 8:3045-3057

Dode C, Levilliers J, Dupont JM, De Paepe A, Le Du N, SoussiYanicostas N, Coimbra RS, Delmaghani S, Compain-Nouaille S, Baverel F, Pecheux C, Le Tessier D, Cruaud C, Delpech M, Speleman F, Vermeulen S, Amalfitano A, Bachelot Y, Bouchard P, Cabrol S, Carel JC, Delemarre-van de Waal H, Goulet-Salmon B, Kottler ML, Richard O, Sanchez-Franco F, Saura R, Young J, Petit C, Hardelin JP (2003) Loss-of-function mutations in FGFR1 cause autosomal dominant Kallmann syndrome. Nat Genet 33:463-465

Eswarakumar VP, Lax I, Schlessinger J (2005) Cellular signaling by fibroblast growth factor receptors. Cytokine Growth Factor Rev 16:139-149

Floyd JA, Gold DA, Concepcion D, Poon TH, Wang X, Keithley E, Chen D, Ward EJ, Chinn SB, Friedman RA, Yu HT, Moriwaki K, Shiroishi T, Hamilton BA (2003) A natural allele of Nxf1 suppresses retrovirus insertional mutations. Nat Genet 35: 221-228

Givol D, Yayon A (1992) Complexity of FGF receptors: genetic basis for structural diversity and functional specificity. FASEB J 6:3362-3369

Grigorescu F, Flier JS, Kahn CR (1986) Characterization of binding and phosphorylation defects of erythrocyte insulin receptors in the type A syndrome of insulin resistance. Diabetes 35:127-138

Grynkiewicz G, Poenie M, Tsien RY (1985) A new generation of $\mathrm{Ca}^{2+}$ indicators with greatly improved fluorescence properties. J Biol Chem 260:3440-3450

Hadari YR, Kouhara H, Lax I, Schlessinger J (1998) Binding of Shp2 tyrosine phosphatase to FRS2 is essential for fibroblast growth factor-induced PC12 cell differentiation. Mol Cell Biol 18: 3966-3973

Hadari YR, Gotoh N, Kouhara H, Lax I, Schlessinger J (2001) Critical role for the docking-protein FRS2 alpha in FGF receptormediated signal transduction pathways. Proc Natl Acad Sci U S A 98:8578-8583

Hajihosseini MK, Lalioti MD, Arthaud S, Burgar HR, Brown JM, Twigg SR, Wilkie AO, Heath JK (2004) Skeletal development is regulated by fibroblast growth factor receptor 1 signalling dynamics. Development 131:325-335

Hanks SK, Quinn AM, Hunter T (1988) The protein kinase family: conserved features and deduced phylogeny of the catalytic domains. Science 241:42-52

Hatch NE, Hudson M, Seto ML, Cunningham ML, Bothwell M (2006) Intracellular retention, degradation, and signaling of glycosylation-deficient FGFR2 and craniosynostosis syndromeassociated FGFR2C278F. J Biol Chem 281:27292-27305

Hebert JM, Lin M, Partanen J, Rossant J, McConnell SK (2003) FGF signaling through FGFR1 is required for olfactory bulb morphogenesis. Development 130:1101-1111

Hoch RV, Soriano P (2006) Context-specific requirements for Fgfr1 signaling through Frs2 and Frs3 during mouse development. Development 133:663-673
Hrabé de Angelis MH, Flaswinkel H, Fuchs H, Rathkolb B, Soewarto D, Marschall S, Heffner S, Pargent W, Wuensch K, Jung M, Reis A, Richter T, Alessandrini F, Jakob T, Fuchs E, Kolb H, Kremmer E, Schaeble K, Rollinski B, Roscher A, Peters C, Meitinger T, Strom T, Steckler T, Holsboer F, Klopstock T, Gekeler F, Schindewolfm C, Jung T, Avraham K, Behrendt H, Ring J, Zimmer A, Schughart K, Pfeffer K, Wolf E, Balling R (2000) Genome-wide, large-scale production of mutant mice by ENU mutagenesis. Nat Genet 25:444-447

Hubbard SR, Wei L, Ellis L, Hendrickson WA (1994) Crystal structure of the tyrosine kinase domain of the human insulin receptor. Nature 372:746-754

Ikeda A, Zheng QY, Zuberi AR, Johnson KR, Naggert JK, Nishina PM (2002) Microtubule-associated protein 1A is a modifier of tubby hearing (moth1). Nat Genet 30:401-405

Inouye M (1976) Differential staining of cartilage and bone in fetal mouse skeleton by alcian blue and alizarin red S. Cong Anom 16:171-173

Jin Y, Pasumarthi KB, Bock ME, Lytras A, Kardami E, Cattini PA (1994) Cloning and expression of fibroblast growth factor receptor-1 isoforms in the mouse heart: evidence for isoform switching during heart development. J Mol Cell Cardiol 26: 1449-1459

Kan M, Wang F, Xu J, Crabb JW, Hou J, McKeehan WL (1993) An essential heparin-binding domain in the fibroblast growth factor receptor kinase. Science 259:1918-1921

Kouhara H, Hadari YR, Spivak-Kroizman T, Schilling J, Bar-Sagi D, Lax I, Schlessinger J (1997) A lipid-anchored Grb2-binding protein that links FGF-receptor activation to the Ras/MAPK signaling pathway. Cell 89:693-702

Lee JM, Kim JY, Cho KW, Lee MJ, Cho SW, Kwak S, Cai J, Jung HS (2008) Wnt11/Fgfrlb cross-talk modulates the fate of cells in palate development. Dev Biol 314:341-350

Li X, Brunton VG, Burgar HR, Wheldon LM, Heath JK (2004) FRS2dependent SRC activation is required for fibroblast growth factor receptor-induced phosphorylation of Sprouty and suppression of ERK activity. J Cell Sci 117:6007-6017

Li C, Scott DA, Hatch E, Tian X, Mansour SL (2007) Dusp6 (Mkp3) is a negative feedback regulator of FGF-stimulated ERK signaling during mouse development. Development 134:167-176

Mallo M (1998) Embryological and genetic aspects of middle ear development. Int J Dev Biol 42:11-22

McLeod MJ (1980) Differential staining of cartilage and bone in whole mouse fetuses by alcian blue and alizarin red S. Teratology 22:299-301

Moffa AB, Ethier SP (2007) Differential signal transduction of alternatively spliced FGFR2 variants expressed in human mammary epithelial cells. J Cell Physiol 210:720-731

Mohammadi M, Schlessinger J, Hubbard SR (1996) Structure of the FGF receptor tyrosine kinase domain reveals a novel autoinhibitory mechanism. Cell 86:577-587

Moller DE, Flier JS (1988) Detection of an alteration in the insulinreceptor gene in a patient with insulin resistance, acanthosis nigricans, and the polycystic ovary syndrome (type A insulin resistance). N Engl J Med 319:1526-1529

Moller DE, Yokota A, Ginsberg-Fellner F, Flier JS (1990) Functional properties of a naturally occurring Trp1200-Ser1200 mutation of the insulin receptor. Mol Endocrinol 4:1183-1191

Nance WE (2003) The genetics of deafness. Ment Retard Dev Disabil Res Rev 9:109-119

Partanen J, Mäkelä TP, Eerola E, Korhonen J, Hirvonen H, ClaessonWelsh L, Alitalo K (1991) FGFR-4, a novel acidic fibroblast growth factor receptor with a distinct expression pattern. EMBO J 10:1347-1354

Partanen J, Schwartz L, Rossant J (1998) Opposite phenotypes of hypomorphic and Y766 phosphorylation site mutations reveal a 
function for Fgfr1 in anteroposterior patterning of mouse embryos. Genes Dev 12:2332-2344

Pau H, Fuchs H, de Angelis MH, Steel KP (2005) Hush puppy: a new mouse mutant with pinna, ossicle, and inner ear defects. Laryngoscope 115:116-124

Pirvola U, Ylikoski J, Trokovic R, Hebert JM, McConnell SK, Partanen J (2002) FGFR1 is required for the development of the auditory sensory epithelium. Neuron 35:671-680

Pirvola U, Zhang X, Mantela J, Ornitz DM, Ylikoski J (2004) Fgf9 signaling regulates inner ear morphogenesis through epithelialmesenchymal interactions. Dev Biol 273:350-360

Pitteloud N, Acierno JS Jr, Meysing AU, Dwyer AA, Hayes FJ, Crowley WF Jr (2005) Reversible Kallmann syndrome, delayed puberty, and isolated anosmia occurring in a single family with a mutation in the fibroblast growth factor receptor 1 gene. J Clin Endocrinol Metab 90:1317-1322

Pitteloud N, Acierno JS, Meysing A, Eliseenkova AV, Ma J, Ibrahimi OA, Metzger DL, Hayes FJ, Dwyer AA, Hughes VA, Yialamas M, Hall JE, Grant E, Mohammadi M, Crowley WF (2006) Mutations in fibroblast growth factor receptor 1 cause both Kallmann syndrome and normosmic idiopathic hypogonadotropic hypogonadism. Proc Natl Acad Sci U S A 103:6281-6286

Rapraeger AC, Krufka A, Olwin BB (1991) Requirement of heparan sulfate for bFGF-mediated fibroblast growth and myoblast differentiation. Science 252:1705-1708

Rice DPC, Rice R, Thesleff I (2003) Fgfr mRNA isoforms in craniofacial bone development. Bone 33:14-27

Riley BM, Mansilla MA, Ma J, Daack-Hirsch S, Maher BS, Raffensperger LM, Russo ET, Vieira AR, Dodé C, Mohammadi M, Marazita ML, Murray JC (2007) Impaired FGF signaling contributes to cleft lip and palate. Proc Natl Acad Sci U S A 104:4512-4517

Rizzoti K, Lovell-Badge R (2007) SOX3 activity during pharyngeal segmentation is required for craniofacial morphogenesis. Development 134:3437-3448

Rozen S, Skaletsky H (2000) Primer3 on the WWW for general users and for biologist programmers. In: Krawetz S, Misener S (eds) Bioinformatics methods and protocols: methods in molecular biology. Humana Press, Totowa, NJ, pp 365-386

Sato N, Katsumata N, Kagami M, Hasegawa T, Hori N, Kawakita S, Minowada S, Shimotsuka A, Shishiba Y, Yokozawa M, Yasuda T, Nagasaki K, Hasegawa D, Hasegawa Y, Tachibana K, Naiki Y, Horikawa R, Tanaka T, Ogata T (2004) Clinical assessment and mutation analysis of Kallmann syndrome 1 (KAL1) and fibroblast growth factor receptor 1 (FGFR1, or KAL2) in five families and 18 sporadic patients. J Clin Endocrinol Metab 89:1079-1088
Schell U, Hehr A, Feldman GJ, Robin NH, Zackai EH, de DieSmulders C, Viskochil DH, Stewart JM, Wolff G, Ohashi H (1995) Mutations in FGFR1 and FGFR2 cause familial and sporadic Pfeiffer syndrome. Hum Mol Genet 4:323-328

Sørensen V, Wiedlocha A, Haugsten EM, Khnykin D, Wesche J, Olsnes S (2006) Different abilities of the four FGFRs to mediate FGF-1 translocation are linked to differences in the receptor C-terminal tail. J Cell Sci 119:4332-4341

Tovey SC, Goraya TA, Taylor CW (2003) Parathyroid hormone increases the sensitivity of inositol trisphosphate receptors by a mechanism that is independent of cyclic AMP. Br J Pharmacol 138:81-90

Toydemir RM, Brassington AE, Bayrak-Toydemir P, Krakowiak PA, Jorde LB, Whitby FG, Longo N, Viskochil DH, Carey JC, Bamshad MJ (2006) A novel mutation in FGFR3 causes camptodactyly, tall stature, and hearing loss (CATSHL) syndrome. Am J Hum Genet 79:935-941

Trokovic N, Trokovic R, Mai P, Partanen J (2003) Fgfrl regulates patterning of the pharyngeal region. Genes Dev 17:141-153

Van Camp G, Smith RJH (2011) Hereditary Hearing Loss Homepage. Available at http://hereditaryhearingloss.org. Accessed 31 March 2011

Wahl MB, Deng C, Lewadoski M, Pourquié O (2007) FGF signaling acts upstream of the NOTCH and WNT signaling pathways to control segmentation clock oscillations in mouse somitogenesis. Development 134:4033-4041

White KE, Cabral JM, Davis SI, Fishburn T, Evans WE, Ichikawa S, Fields J, Yu X, Shaw NJ, McLellan NJ, McKeown C, Fitzpatrick D, Yu K, Ornitz DM, Econs MJ (2005) Mutations that cause osteoglophonic dysplasia define novel roles for FGFR1 in bone elongation. Am J Hum Genet 76:361-367

Wilkie AOM (2008) FGF Receptor mutations: bone dysplasia, craniosynostosis, and other syndromes. In: Epstein CJ, Erickson RP, Wynshaw-Boris A (eds) Inborn errors of development. Oxford University Press, Oxford, pp 461-470

Yamaguchi TP, Harpal K, Henkemeyer M, Rossant J (1994) fgfr-1 is required for embryonic growth and mesodermal patterning during mouse gastrulation. Genes Dev 8:3032-3044

Zhang X, Ibrahimi OA, Olsen SK, Umemori H, Mohammadi M, Ornitz DM (2006) Receptor specificity of the fibroblast growth factor family. The complete mammalian FGF family. J Biol Chem 281:15694-15700

Zhao H, Yang Y, Partanen J, Ciruna BG, Rossant J, Robinson ML (2006) Fibroblast growth factor receptor 1 (Fgfr1) is not essential for lens fiber differentiation in mice. Mol Vis 12:15-25 